\title{
Impact of destruction - Introduction to the Josephus Seminar, Theological University Kampen
}

\begin{tabular}{|c|c|}
\hline \multicolumn{2}{|c|}{$\begin{array}{l}\text { Author: } \\
\text { Koert van Bekkum }{ }^{1,2}\end{array}$} \\
\hline \multicolumn{2}{|c|}{$\begin{array}{l}\text { Affiliations: } \\
{ }^{1} \text { Old Testament at } \\
\text { Theologische Universiteit } \\
\text { Kampen, The Netherlands }\end{array}$} \\
\hline \multicolumn{2}{|c|}{$\begin{array}{l}{ }^{2} \text { Department of New } \\
\text { Testament Studies, Faculty } \\
\text { of Theology, University of } \\
\text { Pretoria, South Africa }\end{array}$} \\
\hline \multicolumn{2}{|c|}{$\begin{array}{l}\text { Dr Koert van Bekkum is a } \\
\text { research associate in the } \\
\text { project 'Biblical Theology and } \\
\text { Hermeneutics', directed by } \\
\text { Prof. Dr Andries G. van Aarde, } \\
\text { professor emeritus and } \\
\text { senior fellow in the Unit for } \\
\text { Advancement of Scholarship } \\
\text { at the Faculty of Theology } \\
\text { of the University of Pretoria, } \\
\text { South Africa. }\end{array}$} \\
\hline \multicolumn{2}{|c|}{$\begin{array}{l}\text { Correspondence to: } \\
\text { Koert van Bekkum }\end{array}$} \\
\hline \multicolumn{2}{|c|}{$\begin{array}{l}\text { Email: } \\
\text { kvanbekkum@tukampen.nl }\end{array}$} \\
\hline \multicolumn{2}{|c|}{$\begin{array}{l}\text { Postal address: } \\
\text { Postbus 5026, } 8260 \mathrm{GA} \\
\text { Kampen, The Netherlands }\end{array}$} \\
\hline \multicolumn{2}{|c|}{$\begin{array}{l}\text { Received: } 19 \text { Mar. } 2015 \\
\text { Accepted: } 22 \text { Apr. } 2015 \\
\text { Published: } 29 \text { July } 2015\end{array}$} \\
\hline \multicolumn{2}{|c|}{$\begin{array}{l}\text { How to cite this article: } \\
\text { Van Bekkum, K., 2015, } \\
\text { 'Impact of destruction - } \\
\text { Introduction to the Josephus } \\
\text { Seminar, Theological } \\
\text { University Kampen', } \\
\text { HTS Teologiese Studies/ } \\
\text { Theological Studies 71(1), Art. } \\
\text { \#2943, } 3 \text { pages. http://dx.doi. } \\
\text { org/10.4102/hts.v71i1.2943 }\end{array}$} \\
\hline \multicolumn{2}{|c|}{$\begin{array}{l}\text { Copyright: } \\
\text { (C) 2015. The Authors. } \\
\text { Licensee: AOSIS } \\
\text { OpenJournals. This work is } \\
\text { licensed under the Creative } \\
\text { Commons Attribution } \\
\text { License. }\end{array}$} \\
\hline \multicolumn{2}{|l|}{ Read online: } \\
\hline 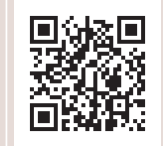 & $\begin{array}{l}\text { Scan this QR } \\
\text { code with your } \\
\text { smart phone or } \\
\text { mobile device } \\
\text { to read online. }\end{array}$ \\
\hline
\end{tabular}

This is an introduction to the contributions of Jan Willem van Henten and William den Hollander to the Josephus Seminar 'Impact of destruction. Methodological questions in the study of Jewish and Christian reactions to the demolition of the Temple' held at the Theological University in Kampen, the Netherlands. The introduction sketches the status quaestionis and the methodological issues in comparing the works of Josephus and the Gospels in reconstructing the impact of the destruction of the Temple in AD 70 on Judaism and Early Christianity.

\section{Introduction}

On 23 September 2014 a Josephus Seminar was held at the Theological University in Kampen, the Netherlands, entitled 'Impact of destruction. Methodological questions in the study of Jewish and Christian reactions to the demolition of the Temple.' The main reason for this meeting was the recent appearance and positive reception of a monograph by the visiting postdoctoral scholar, Dr William den Hollander (Den Hollander 2014; cf. e.g. Adams 2014; Lim 2015; Tuval 2014; Wiseman 2014). His study of several episodes in the life of Flavius Josephus and their evaluation in the light of broader historical evidence turns out to be helpful in answering the question of to what extent Josephus's writings can be used in historical reconstruction and in imagining the vicissitudes and motives of those who acted in 1st century AD Galilee, Judaea and Rome. Accordingly, it seemed interesting to create an occasion of interaction between Den Hollander and several Josephus scholars in the Netherlands, among whom intense reflection is taking place on the application of historiographical and historical methods to Josephus (e.g. Jonquière 2007; Popović 2011; Van Henten 2007, 2011). In addition, the question needs to be asked about what the implications of these methodological analyses of the life and works of Flavius Josephus are for theological studies. Hence, the subject of the seminar was determined to be the value and relationship of biblical and non-biblical sources and material culture for biblical interpretation and historical reconstruction, regarding the immediate impact of the destruction of the Temple on both Judaism and Early Christianity.

In general, three main sources are to be distinguished in the study of the history of the Southern Levant: The material culture as it emerges from archaeological research; non-biblical textual and iconographic evidence, such as historiographical works and epigraphic and numismatic remains; and finally the biblical texts. It is important to value the distinct nature of each of these types of sources before they can be used for historical reconstruction, for they are quite dissimilar and reveal different aspects of society. But what does that mean in trying to offer a comprehensive historical reconstruction? A closer look at the most important sources related to the destruction of the Temple in $70 \mathrm{AD}$ immediately reveals that they are also interconnected and that not only material and historical, but also ideological and theological factors come into play. Firstly, there are the material remains of the magnificent Herodian Temple, of which the immense foundations are still visible in Jerusalem. Secondly, Josephus himself offers a vivid description of the destruction of the Temple in his The Jewish War:

Caesar, finding himself unable to restrain the impetuosity of his frenzied soldiers and that the fire was gaining the mastery, passed with his generals within the building and beheld the holy place of the sanctuary and all that it contained - things far exceeding the reports current among foreigners and not inferior to their proud reputation among our own nation. As the flames had nowhere yet penetrated to the interior, but were consuming the outbuildings of the sanctuary, Titus, rightly supposing that the structure might still be preserved, rushed out and endeavoured by personal appeals to induce the soldiers to quench the fire (...). But their respect for Caesar and their fear of the officer who was endeavouring to check them were overpowered by their rage, their hatred of the Jews and the lust of battle, an even mightier master. (...) Thus against Caesar's wishes, was the temple set on fire.

Deeply as one must mourn for the most marvellous edifice which we have ever seen or heard of, whether we consider its structure, its magnitude, the richness of its every detail, or the reputation of 
its Holy Places, yet may we draw very great consolation from the thought that there is no escape from Fate, for works of art and places any more than for living beings. And one may well marvel at the exactness of the cycle of the Dynasty; for, as I said, she waited until the very month and the very day on which in bygone times the temple had been burned by the Babylonians. From its first foundation by King Solomon up to its present destruction, which took place in the second year of Vespasian's reign, the total period amounts to one thousand one hundred and thirty years seven months and fifty days; from its rebuilding by Haggai in the second year of the reign of Cyrus until its fall under Vespasian to six hundred and thirty nine years and fortyfive days. (Thackeray 1928, War 6:260-267)

A totally different depiction is found in the words in the Gospel of Mark 13:1-5, (New International Version [NIV]), where Jesus looks forward to the destruction of the Temple:

As he was leaving the temple, one of his disciples said to him, 'Look, Teacher! What massive stones! What magnificent buildings!' 'Do you see all these great buildings?' replied Jesus. 'Not one stone here will be left on another; everyone will be thrown down.' As Jesus was sitting on the Mount of Olives opposite the temple, Peter, James, John and Andrew asked him privately, 'Tell us, when will these things happen? And what will be the sign that they are all about to be fulfilled?' Jesus said to them: 'Watch out that no one deceives you.

In these texts and material remains, several elements come together. Firstly, all sources confirm the magnificent impression of this superior building, the Temple, which is not only material in nature, but also plays an important part in the ideological communication of Herod the Great (cf. e.g. Netzer 2006). In addition, this building is in various ways connected to the history of Israel, and to God's interactions with the people of Israel. The interpreters of the material remains have to deal with their apparent cultic function in the past (and present). Josephus also looks backwards and reminds his readers of Divine providence, connecting the destruction of the Temple to its foundation by Solomon and the destruction by the Babylonians. In the Gospel of Mark, however, Jesus in turn looks forward to the end of history in apocalyptic language, comparing God's judgement with a Lord coming back to his household (cf. e.g. Wright 1996:339-366). Accordingly, all of these sources are both closely connected and filled with different perspectives and political and theological convictions. How is the relation between them to be defined? How should this history be reconstructed? Does it matter how the historian values the perceptions of history in these accounts?

It is clear that the destruction of the Temple had a great impact on the nature and development of both Judaism and the Early Church. But two examples may suffice to explain that a difference in view of the sources also leads to diverse reconstructions of this impact. Is Josephus's statement that the Temple was set on fire against Caesar's wishes reliable? It has been argued that this is not the case and that it is more reasonable to assume that the decision to destroy the Temple had been taken before the final confrontation (Pucci Ben Zeev 2011; for a different view, see Leoni 2007). Undoubtedly, a more comprehensive view of Josephus's ideas about the Temple helps in making a decision in this respect. In a similar way, a deeper understanding of Jesus as a Prophet, and his view of the Temple and of the way his words have been used to write the Gospel of Mark, clear the way to a contextual interpretation of his saying that 'not one stone here will be left on another' (Mk 13:2).

The major contributions to the Josephus Seminar in Kampen, hereby published as the next two articles in this issue of HTS Teologiese Studies/Theological Studies, shed important light on these two subjects. Jan Willem van Henten, the most important senior Josephus scholar in the Netherlands, deconstructs the well-known Christian view of Flavius Josephus as the 5th evangelist. In his view both Jesus of Nazareth and Josephus considered the Temple still to be relevant, albeit in very different ways. Josephus's perspective on the Temple changes in his works. He may even have reckoned with the possibility that the Temple was going to be rebuilt if the Romans allowed for it to happen.

With regard to Josephus, William den Hollander's sketch of Josephus's theological view of the Temple as based on the conviction of the God of Israel's self-revelation in scripture can be read as a complement to Van Henten's reconstruction. Both scholars firmly disagree, however, with each other's views concerning the original meaning of Jesus' statements about the Temple. Van Henten argues at length that none of these statements in their original context necessarily implies that the institution of the Temple would stop functioning in the near future or at the end of time. In Den Hollander's view, however, both the prophetic value and the metanarrative of scripture in Judaism before $70 \mathrm{AD}$ make it plausible to assume that Jesus indeed predicted the destruction of the Temple. The major difference between Josephus and Jesus lies rather in the question of which sins exactly were judged to be responsible.

From a methodological point of view, this exchange of arguments turns out to be decidedly fruitful. Both scholars show mastery as practical craftsmen in searching for the right interpretation of concrete texts. Moreover, their explicit remarks on the nature of and relation between the sources make it possible to understand their methodological approach. Finally, these contributions also highlight that the influence of theological convictions, both in ancient and (post)modern times, on historical reconstruction can be discussed in a scholarly manner. In this way, Van Henten and Den Hollander indeed contribute to the question of the value and relationship of biblical and non-biblical sources and material culture for biblical interpretation and historical reconstruction.

\section{Acknowledgements Competing interests}

The author declares that he has no financial or personal relationships which may have inappropriately influenced him in writing this article. 


\section{References}

Adams, S.A., 2014, Review of Josephus, the emperors, and the city of Rome: From hostage to historian, by W. den Hollander', Bryn Mawr Classical Review 6, 33.

Den Hollander, W., 2014, Josephus, the emperors, and the city of Rome: From hostage to historian, Brill, Leiden. (Ancient Judaism and Early Christianity, 86).

Jonquière, T., 2007, Prayer in Josephus, Leiden, Brill. (Ancient Judaism and Early Christianity, 70)

Leoni, T., 2007, “'Against Caesar's Wishes": Josephus as a source for the burning of the temple', Journal of Jewish Studies 58, 39-51.

Lim, S.U., 2015, Review of Josephus, the emperors, and the city of Rome: From hostage to historian, by W. den Hollander', Journal of Theological Studies 66, 1-3. http:// dx.doi.org/10.1093/jts/flu214

Netzer, E., 2006, The architecture of Herod, the great builder, Mohr Siebeck, Tübingen. (Texts and Studies in Ancient Judaism, 117).

Popović, M., 2011, 'The Jewish revolt against Rome: Sources, history, perspectives', in M. Popović (ed.), The Jewish revolt against Rome: Interdisciplinary perspectives, pp. 1-25, Brill, Leiden. (Supplements to the Journal for the Study of Judaism, 156). http://dx.doi.org/10.1163/ 9789004216693_002
Pucci Ben Zeev, M., 2011, 'Between fact and fiction: Josephus' account of the destruction of the temple', in J. Pastor, P. Stern \& M. Mor (eds.), Flavius Josephus: Interpretation and history, pp. 53-64, Brill, Leiden. (Supplements to the Journal Interpretation and history, $\mathrm{pp}$.
for the Study of Judaism, 146).

Thackeray, H.S.J., 1928, Josephus - The Jewish War, vol. 3, Book 5-7, transl. H.S.J. Thacheray, Harvard University Press, Cambridge. (Loeb Classical Library, 210).

Tuval, M., 2014, Review of Josephus, the emperors, and the city of Rome: From hostage to historian, by W. den Hollander, Sehepunkte 14(11), viewed 04 May 2015, from http://www.sehepunkte.de/2014/11/25028.html

Van Henten, J.W., 2007, 'Noble death in Josephus. Just Rhetoric?' in Z. Rogers (ed.), Making History: Josephus and historical method, pp. 195-218, Brill, Leiden. (Supplements to the Journal for the Study of Judaism, 110). http://dx.doi. org/10.1163/ej.9789004150089.i-471.73

Van Henten, J.W., 2011, 'Rebellion under Herod the great and Archelaus. Prominent motifs and narrative function', in M. Popović (ed.), The Jewish revolt against Rome: Interdisciplinary perspectives, pp. 241-270, Brill, Leiden. (Supplements to the Journal for the Study of Judaism, 156). http://dx.doi. org/10.1163/9789004216693 009

Wiseman, T.P., 2014, 'Review of Josephus, the emperors, and the city of Rome: From hostage to historian by W. den Hollander', Classical Review 64, 1-2.

Wright, N.T., 1996, Jesus and the victory of God, Christian origins and the question of God 2, Society for Promoting Christian Knowledge, London. 